\title{
SEROTONIN GENE POLYMORPHISMS AND PSYCHIATRY COMORBIDITIES IN TEMPORAL LOBE EPILEPSY
}

ANA CLAUDIA DE SOUZA; LAILA CIGANA SCHENKEL; JOSÉ AUGUSTO BRAGATTI; JULIANA ALLEBRAND BECKER; CAROLINA MACHADO TORRES; KELIN CRISTINE MARTIN; GISELE GUS MANFRO; SANDRA LEISTNER-SEGAL; MARINO MUXFELDT BIANCHIN

INTRODUCTION: Among epileptic patients, those with temporal lobe epilepsy (TLE) are at risk to develop psychiatric disorders. Evidence suggests that the association of psychiatric disorders with epilepsy might be related to common biological substrates. Studies support that serotonin $(5-\mathrm{HT})$ may also contribute to a predisposition to epilepsy. The 5-HTTLPR and 5-HTTVNTR polymorphisms in the $5-\mathrm{HTT}$ gene and the $\mathrm{C}-1019 \mathrm{G}$ polymorphism in the $5-\mathrm{HT} 1 \mathrm{~A}$ gene have been studied in psychiatric diseases. As far as we know, this is the first study evaluating a possible genetic involvement in the development of psychiatric comorbidities in epilepsy. OBJECTIVE: It is biologically plausible that alterations in serotonin-related genes may be involved in higher susceptibility to psychiatric disease in the individuals with TLE. Here we report results of an association study of serotonin gene polymorphisms and psychiatry comorbidities in TLE. METHODS: Case-control study of 155 patients with temporal lobe epilepsy. We evaluate the influence of 5-HTTLPR and 5-HTTVNTR polymorphisms in the 5-HTT gene and the C-1019G polymorphism in the 5-HT1A gene in psychiatric comorbidities of TLE. RESULTS: After logistic regression, female sex (O.R. $=2.38 ; 95 \% \mathrm{CI} 1.08$ to $5.28 ; \mathrm{p}=0.03)$ and the presence of $\mathrm{C}$ allele of $5-\mathrm{HT} 1 \mathrm{~A} \mathrm{C}-1019 \mathrm{G}$ polymorphism (O.R. $=2.82 ; 95 \%$ CI 1.02 to $7.81 ; p=0.04)$ remained independent risk factors for anxiety disorders in temporal lobe epilepsy (O.R.=2.82; 95\% CI 1.02 to $7.81 ; p=0.04)$. CONCLUSION: C allele of 5-HT1A C-1019G polymorphism is independent risk factor for anxiety disorders in temporal lobe epilepsy. Other studies will shade some light on molecular mechanisms involved in psychiatric comorbidities in epilepsy. Financiamento: CNPQ e FIPE-HCPA 